\title{
Toxicity of antiglaucoma drugs with and without benzalkonium chloride to cultured human corneal endothelial cells
}

This article was published in the following Dove Press journal:

Clinical Ophthalmology

14 October 2010

Number of times this article has been viewed

\author{
Masahiko Ayaki' \\ Atsuo Iwasawa ${ }^{2}$ \\ Yoichi Inoue ${ }^{3}$ \\ 'Department of Ophthalmology, \\ Saitama National Hospital, Wako, \\ Japan; ${ }^{2}$ Life Particle Interaction \\ Engineering Creation, New Industry \\ Creation Hatchery Center, Tohoku \\ University, Sendai, Japan; ${ }^{3}$ Department \\ of Ophthalmology, Olympia Eye \\ Hospital, Tokyo, Japan
}

Purpose: The toxicity of antiglaucoma medications to ocular surface cells has been evaluated extensively; however, the toxicity to corneal endothelial cells (CECs) remains elusive. Our aim is to evaluate the toxicity of antiglaucoma medications to CECs using an in vitro toxicity assay.

Methods: Primary cultures of human (H) CECs derived from eye bank specimens were established. Following exposure of HCECs to test solutions for 10, 30, or 60 minutes, or 48 hours, we measured cell viability using a WST-1 assay. Test solutions were diluted in culture media and included $0.5 \%$ Timoptol $^{\circledR}$, preservative-free $0.5 \%$ timolol maleate, $1 \%$ Trusopt $^{\circledR}$, preservativefree $1 \%$ dorzolamide, $\operatorname{Travatan}^{\circledR}$, Travatan $\mathrm{Z}^{\circledR}$, Xalatan ${ }^{\circledR}$, and benzalkonium chloride (BAK). To assess cell viability, the value of the test culture well after treatment was expressed as a percentage of that of the control well. Toxicity of each solution was compared using the cell viability score (CVS).

Results: After exposure to 10 -fold dilutions of test solutions for 48 hours, HCEC viabilities were $48.5 \%$ for $0.5 \%$ Timoptol, $80.9 \%$ for preservative-free $0.5 \%$ timolol maleate, $47.0 \%$ for $1 \%$ Trusopt, $71.7 \%$ for preservative-free $1 \%$ dorzolamide, $55.5 \%$ for Travatan, $88.5 \%$ for Travatan Z, and $52.5 \%$ for Xalatan. Exposure to test solutions diluted 100 -fold or more resulted in HCEC viabilities $>80 \%$, with the exception of preservative-free $1 \%$ dorzolamide, which resulted in a viability of $72.0 \%$ at a dilution of 100 -fold. Based on CVS, the order of cell viability was Travatan $\mathrm{Z} \geq$ preservative-free timolol maleate $=$ preservative-free dorzolamide $>0.5 \%$ Timoptol $=1 \%$ Trusopt $>$ Travatan $\geq$ Xalatan. Assessment of the combined effect of drug and BAK revealed that latanoprost reduced the toxicity of BAK.

Conclusion: Antiglaucoma eye drops produced HCEC toxicity that appeared to depend on the presence of BAK. Because dilution of the antiglaucoma solutions resulted in markedly lower HCEC toxicity, HCEC damage due to antiglaucoma medication may occur only in rare cases. The CVS was useful for comparison of the toxicity of the drugs.

Keywords: cell viability score, eye drop, preservatives

\section{Introduction}

The effects of antiglaucoma drugs on the ocular surface have been investigated extensively. ${ }^{1-4}$ Special attention has been paid to the cytotoxicity of benzalkonium chloride (BAK), included in solutions as a preservative. ${ }^{5-11}$ Glaucoma surgery using mitomycin C leads to a reduction in the density of corneal endothelial cells (CECs). ${ }^{12}$ By comparison, little is known about the toxicity of antiglaucoma eye drops to CECs. ${ }^{13-16}$ The aim of the present study is to evaluate the toxicity of antiglaucoma medications on human $(\mathrm{H})$ CECs using a cell culture system. Our investigation will contribute to better long-term patient care especially in the cases with decreased CEC density and history of invasive intraocular surgeries, since glaucoma medication may continue throughout life. 


\section{Methods}

The present study was approved by the Institutional Review Board of Showa University, Fujigaoka Rehabilitation Hospital (formerly the affiliation of the corresponding author).

We established primary cultures of HCECs derived from human eye bank specimens (SightLife, Seattle, Washington, USA), as described previously. ${ }^{17}$ When sufficient cell numbers for bioassay were obtained, cells were harvested. A $100-\mu \mathrm{L}$ aliquot of the culture, containing approximately $2 \times 10^{4}$ cells, was replated, and cells were cultured for 2 days before exposure to test solutions. Table 1 shows the antiglaucoma solutions evaluated in the present study. Preservative-free $0.5 \%$ timolol maleate and preservativefree $1 \%$ dorzolamide were prepared for the present investigation only. Test solutions were used undiluted or diluted 2-, 10-, 100-, 1,000-, or 10,000-fold. $0.01 \%$ and $0.005 \%$ BAK (Wako Pure Chemical Industries, Osaka, Japan) were also tested.

After exposure to the test solutions for 10,30 , or 60 minutes, or 48 hours, cell viability was assayed using 4-[3-(4-iodophenyl)2-(4-nitrophenyl)-2H-5-tetrazolio]-1,3-benzene disulfonate (WST-1; Dojindo Laboratories, Kumamoto, Japan). The WST-1 assay is a quantitative colorimetric assay that measures mitochondrial activity as an index of cell viability and proliferation. It only detects living cells, and the signal generated is directly proportional to the number of live cells. At the completion of the assays, absorbance was read on a spectrophotometer (Benchmark microplate reader; Bio-Rad, Hercules, California, USA). Control wells were incubated with growth media without test solution. To calculate cell viability, the value of the signal from the treated culture well was expressed as a percentage of that of the control well. Experiments were repeated between 8 and 16 times, and results were expressed as the mean \pm standard deviation. The first established cell line was used for assays after 48 hours' exposure, and the second one was for 10, 30, and 60 minutes' exposure. Each of these was cultivated from 4 corneas. Statistical analysis with Student's $t$ test was performed using Microsoft Excel (Tokyo, Japan).

We expressed the results of the viability of cells after 10 , 30 , or 60 minutes' exposure as a cell viability score (CVS) to enable easy comparison of the effects of different drugs. This concept is similar to the minimum inhibitory concentration $\left(\mathrm{MIC}_{50}\right)$ of a drug required to inhibit the growth of $50 \%$ of organisms. CVSs are calculated as follows: (1) The toxicological tests are performed in undiluted, 2-fold or 10 -fold diluted solutions for 10, 30, or 60 minutes' exposure. (2) The cell viability value in any solution is found to be $<80 \%$ in any conditions, and confirmed cell viability is $\geq 80 \%$ after adequate dilutions for every solution. (3) The CVS50 is determined for each solution in each condition as the number of experiments for a viability value $\geq 50 \%$. The CVS40/80 is calculated as follows: CVS40/80 = (number of experiments for a viability value $>80 \%$ ) - (number of

Table I Antiglaucoma eye drops evaluated in the present study

\begin{tabular}{|c|c|c|c|c|}
\hline Active component & $\begin{array}{l}\text { Trade name } \\
\text { and manufacturer }\end{array}$ & Preservative & CVS50 & CVS40/80 \\
\hline Timolol maleate $(0.5 \%)$ & $\begin{array}{l}\text { 0.5\% Timoptol (Banyu } \\
\text { Pharmaceutical, Tokyo, Japan) }\end{array}$ & $0.005 \%$ BAK & 5 & $\begin{array}{l}2 \\
(4-2)\end{array}$ \\
\hline Preservative-free timolol maleate $(0.5 \%)$ & $\begin{array}{l}\text { No trade name and prepared for } \\
\text { investigational use only. Provided } \\
\text { by Merck and Co, Whitehouse } \\
\text { Station, NJ, USA }\end{array}$ & none & 9 & $\begin{array}{l}7 \\
(7-0)\end{array}$ \\
\hline Dorzolamide (I\%) & $\begin{array}{l}\text { I\% Trusopt (Banyu } \\
\text { Pharmaceutical) }\end{array}$ & $0.005 \%$ BAK & 6 & $\begin{array}{l}2 \\
(5-3)\end{array}$ \\
\hline Preservative-free dorzolamide (I\%) & $\begin{array}{l}\text { No trade name and prepared for } \\
\text { investigational use only. Provided } \\
\text { by Merck and Co }\end{array}$ & none & 9 & $\begin{array}{l}6 \\
(6-0)\end{array}$ \\
\hline Travoprost $(0.004 \%)$ & $\begin{array}{l}\text { Travatan (Alcon Laboratories, } \\
\text { Fort Worth, TX, USA) }\end{array}$ & $0.015 \%$ BAK & 4 & $\begin{array}{l}0 \\
(3-3)\end{array}$ \\
\hline Travoprost $(0.004 \%)$ & Travatan Z (Alcon Laboratories) & SofZia system & 9 & $\begin{array}{l}9 \\
(9-0)\end{array}$ \\
\hline Latanoprost $(0.005 \%)$ & $\begin{array}{l}\text { Xalatan (Pfizer, New York, } \\
\text { NY, USA) }\end{array}$ & $0.02 \%$ BAK & 3 & $\begin{array}{l}-4 \\
(2-6)\end{array}$ \\
\hline
\end{tabular}

Note: ${ }^{\text {TTh }}$ CVS was calculated after 10, 30, or 60 minutes' exposure of each drug as follows: CVS40/80 = (number of viability values $>80 \%$ ) $-($ number of viability values $<40 \%$ ); CVS50 $=$ number of viability value $\geq 50 \%$.

Abbreviations: CVS, cell viability score; BAK, benzalkonium chloride; SofZia, an ionic buffering preservative system containing borate, sorbitol, propylene glycol, and zinc. ${ }^{11,34}$ 
experiments for viability value $<40 \%$ ). (4) A total of CVS for multiple ( 2 or more concentrations or exposure times) conditions is relevant for general evaluation. Although some CVS for a single condition seems suitable to determine the order of toxicity such as 2-fold dilution after 30 or $60 \mathrm{~min}$ utes' exposure (eg, Figure 1), note especially that these results are not always consistent with the result from a total of CVS or the general trend observed in graphic expression. (5) As for determination of the order of toxicity of the tested solutions, the significant difference in actual scores should be $>20 \%$ of a total number of experiments under the condition for CVS. Consequently, the order of toxicity is expressed by " $<$ " and " $>$ " for the difference $\geq 20 \%$, " $\leq$ ", " $\geq$ ", and " = " for the difference from $0 \%$ to $20 \%$. In the present study, a total of 9 experiments were conducted, and we defined significant difference as 2 or more scores. When the orders determined by CVS50 and CVS40/80 are conflicting, a final decision is made by uniting both results or by considering CVS for individual concentration or exposure time to explore the trend. The CVS system is subject to change according to tested solutions, cell lines, toxicological methods, and other factors. We used CVS in prior studies ${ }^{18-20}$ and found it useful. Comparisons of cell viability were also made between a drug with BAK and the corresponding drug without BAK.

\section{Results}

The cell viabilities of HCECs exposed to test solutions are shown in Figure 1. HCEC viabilities after exposure to 10 -fold dilutions of test solutions for 48 hours were, eg, $48.5 \%$ for $0.5 \%$ Timoptol $^{\circledR}$ (Banyu Pharmaceutical, Tokyo, Japan), $80.9 \%$ for preservative-free $0.5 \%$ timolol maleate, $47.0 \%$ for $1 \%$ Trusopt $^{\circledR}$ (Banyu Pharmaceutical), $71.7 \%$ for preservative-free $1 \%$ dorzolamide, $55.5 \%$ for Travatan ${ }^{\circledR}$ (Alcon Laboratories, Fort Worth, Texas, USA), 88.5\% for Travatan $Z^{\circledR}$ (Alcon Laboratories), and $52.5 \%$ for Xalatan ${ }^{\circledR}$ (Pfizer, New York, NY, USA). Cell viability $>80 \%$ was seen after incubation with 100 -fold dilutions of test solutions, with the exception of preservative-free $1 \%$ dorzolamide, which resulted in $72.0 \%$ viability. We confirmed cell viability exceeded $80 \%$ in 1,000 -fold or 10,000 -fold dilution for every solution including 48 hours' exposure. Using CVS as an indicator of cytotoxicity, the order of cell viability after short exposure (10,30, or 60 minutes)

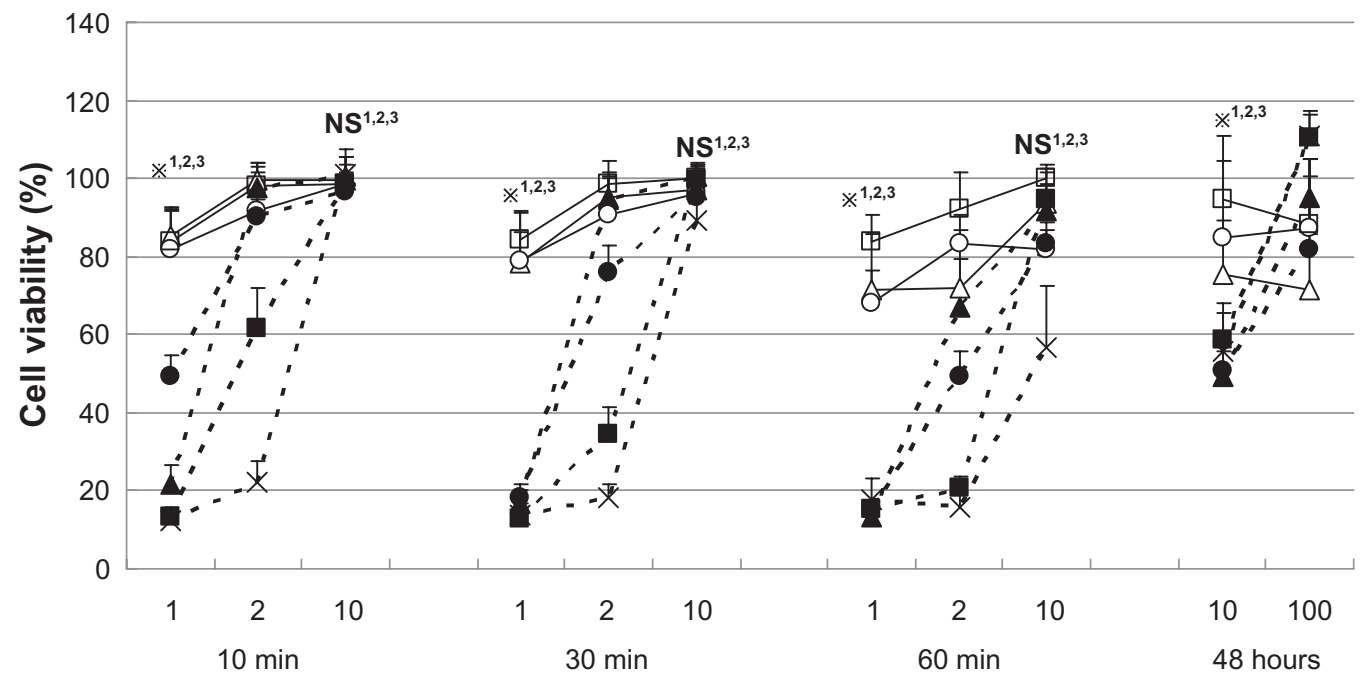

Fold dilution and exposure time
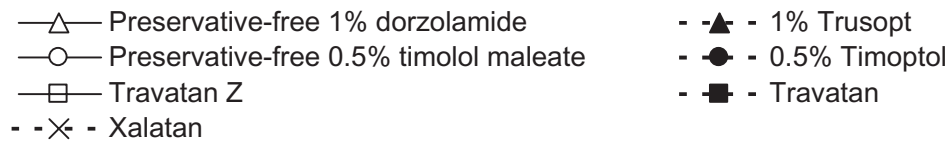

Figure I Viability of cultured human corneal endothelial cells after exposure to antiglaucoma eye drops for 10, 30, or 60 minutes, or 48 hours. Exposure to drugs containing the preservative benzalkonium chloride led to markedly lower cell viability, especially at higher concentrations and following longer exposure. Data are expressed as the mean \pm standard deviation. Drugs without benzalkonium chloride are represented by open symbols and solid lines.

Note: $* P<0.01$ (Student's $t$ test) or NS for comparisons of ${ }^{* 1, N S I}$ Timoptol vs preservative-free timolol maleate; ${ }^{22, N s 2}$ Trusopt vs preservative-free dorzolamide, and *3,NS3 Travatan vs Travatan $\mathrm{Z}$ in each concentration and exposure time.

Abbreviation: NS, nonsignificant. 
to the solutions was Travatan $\mathrm{Z} \geq$ preservative-free timolol maleate $=$ preservative-free dorzolamide $>0.5 \%$ Timoptol $=1 \%$ Trusopt $>$ Travatan $\geq$ Xalatan (Table 1). As for the cell viability after 48 hours' exposure, the difference between the solutions with BAK and those without BAK was clear in 10-fold dilution (Figure 1, far right panel). However, cell viabilities were $>70 \%$ in all of the 100 -fold diluted solutions and the difference was not clear. We assessed the effect of antiglaucoma medications with and without BAK statistically, which revealed that cell viability in the presence of BAK was markedly lower, especially with higher concentrations and following longer exposure (Figure 1).

Cell viabilities following treatment with BAK alone or antiglaucoma solutions containing comparable BAK concentrations are shown in Figure 2. Cell viabilities were lower for $0.5 \%$ Timoptol and $1 \%$ Trusopt than for $0.005 \%$ BAK $(P<0.01)$. In comparison, higher cell viabilities were seen with Xalatan (used at a 2-fold dilution, containing 0.01\% BAK) and Travatan (used at a 2-fold dilution, containing $0.0075 \%$ BAK) than for $0.01 \%$ BAK alone $(P<0.01$, $P<0.01)$.

\section{Discussion}

BAK is toxic for CECs, and several clinical cases have been reported $^{21-25}$ for accidental introduction of BAK into the anterior chamber and for instillation of BAK-containing solutions to the eyes with or without disrupted ocular surface barrier function. The antiglaucoma medications containing BAK were significantly more toxic to HCECs than solutions without BAK. Our results are similar to those of other studies using ocular surface cells. ${ }^{1-11}$ Considering the actual concentration of drugs (1,000- to 10,000-fold dilution in aqueous humor $)^{26,27}$ to which HCECs are exposed after topical administration and the fact that toxicity decreased markedly after dilution in the present study, HCEC loss due to antiglaucoma medication may only occur in rare cases.

Timolol maleate was the standard antiglaucoma medication until prostaglandin analogs were introduced. Previous studies of its side effects on ocular surface cells demonstrated that timolol maleate itself has acceptable toxicity and that BAK and other ingredients in commercial timolol maleate eye drops, as well as interaction of each component, play a major role in their toxicity, ${ }^{9,28,29}$ which was confirmed by the present results for HCECs. Treatment with Trusopt has been reported to result in corneal edema; however, this side effect only appeared in patients with compromised corneas and a previous history of corneal pathology. ${ }^{30}$ Previous studies and the results of the present study suggest that Trusopt and preservative-free dorzolamide are not significantly toxic to CECs under usual ocular conditions. ${ }^{15,29,31-33}$

Travatan Z was less toxic to HCECs than Travatan containing the preservative BAK. Travatan $Z$ uses SofZia, a unique

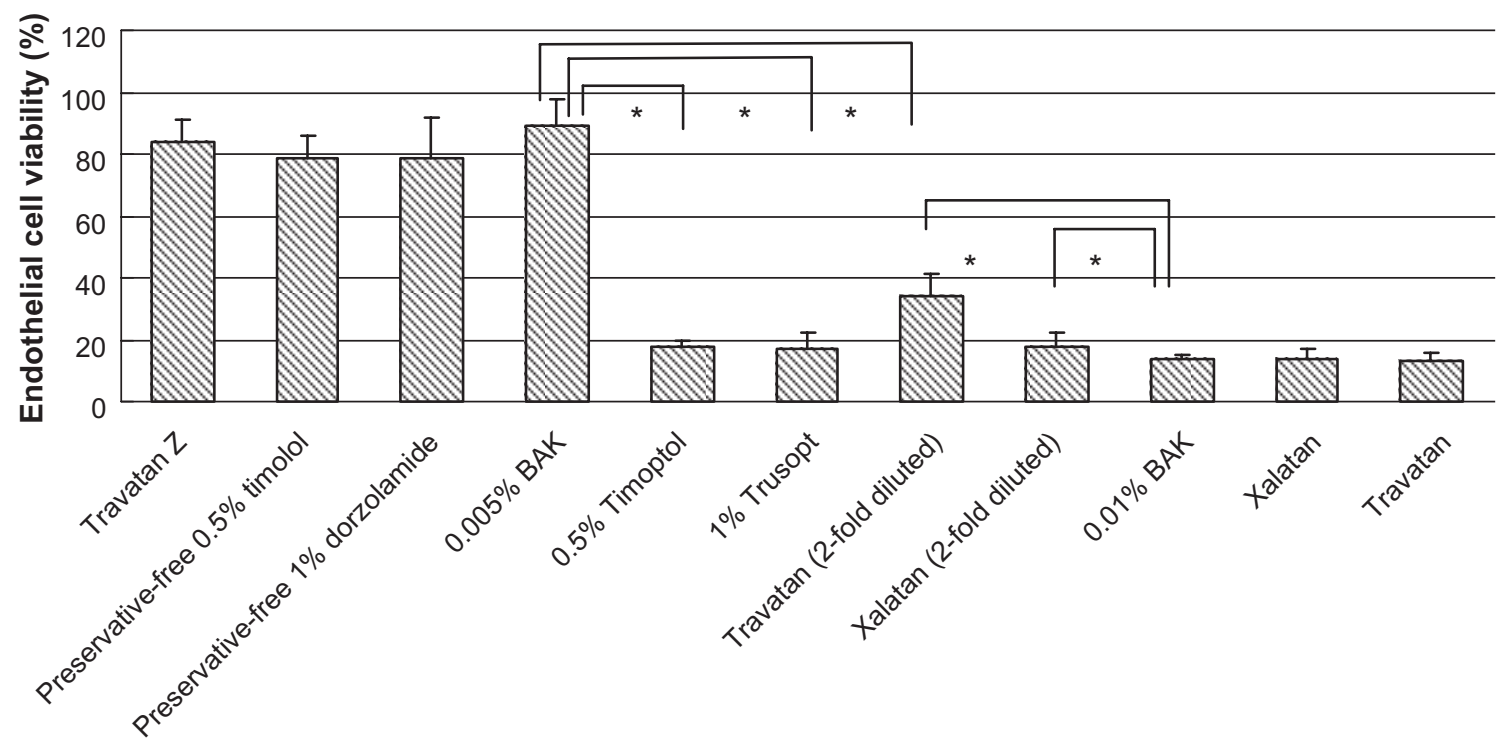

Figure 2 Effect of antiglaucoma eye drops and BAK on the viability of cultured human corneal endothelial cells after 30 minutes' exposure. BAK was used at concentrations of $0.01 \%$ and $0.005 \%$. Note that cell viabilities were lower for $0.5 \%$ Timoptol and I\% Trusopt than for $0.005 \%$ BAK. In comparison, higher cell viabilities were seen with Xalatan (used at a 2-fold dilution, containing $0.01 \%$ BAK) and Travatan (used at a 2-fold dilution, containing $0.0075 \%$ BAK) than for $0.01 \%$ BAK alone.

Note: Data are expressed as the mean \pm standard deviation. $* P<0.01$ (Student's $t$ test).

Abbreviation: BAK, benzalkonium chloride. 
ionic buffering preservative system containing borate, sorbitol, propylene glycol, and zinc. ${ }^{11,34}$ Our assessment of the combined effect of antiglaucoma compounds and BAK revealed that cell viability for timolol maleate (Timoptol) and dorzolamide (Trusopt) eye drops with BAK was much lower than that for comparable concentration of BAK, whereas latanoprost (Xalatan), and probably travoprost (Travatan) did not exhibit lower cell viability to HCECs than BAK alone (Figure 2). Our results on HCECs could not confirm previous findings for a protective effect of latanoprost and travoprost against the toxicity of BAK on conjunctival cells. ${ }^{35}$ Owing to the limited number of cultured HCECs available, we were not able to examine the effect of BAK at exactly the same concentration as that contained in Travatan. Further investigations with additional methodologies are necessary to properly evaluate the cytotoxicity of antiglaucoma medications.

The comparison of drug toxicity with graphic expression of a series of measurements is often difficult. Using CVS reference values of $40 \%, 50 \%$, or $80 \%$ enables numerical expression, leading to a better comparison of solution toxicity. The reference point of 50\% for CVS50 is a direct application of $\mathrm{MIC}_{50} .80 \%$ for CVS40/80 is a border between nontoxic and toxic, and $40 \%$ is a border between toxic and very toxic according to our experience of assay with numerous cells and reagents. The CVS was a useful evaluation method for comparison of cell viability values obtained from multiple series of toxicity assays.

The concentration of tested solutions was very high compared with the actual concentration in aqueous humor after instillation, because the present study is a so-called accelerated experiment. We were unable to construct a culture system to observe toxicity over a long time in the solution of very low concentration. Consequently, we set up experiments in solutions of high concentrations to detect significant toxicity after reasonable incubation. The major difficulties in eye drop toxicity studies include setting exposure time and concentration, since both tear and aqueous humor are continuously exchanged in a living eye. This is the reason why our setting covers many exposure times and dilutions to explore toxicity in various environments. The short exposures may simulate accidental introduction of the drug to endothelial cells, and 48 hours' exposure may simulate long-term or repeated instillations.

\section{Conclusion}

Antiglaucoma eye drops produced HCEC toxicity that appeared to depend on the presence of BAK. The CVS was useful in comparing the cytotoxicity of different drugs, and the order of cell viability in tested solutions determined by CVS was Travatan $\mathrm{Z} \geq$ preservative-free timolol maleate $=$ preservative-free dorzolamide $>0.5 \%$ Timoptol $=1 \%$ Trusopt $>$ Travatan $\geq$ Xalatan. Because dilution of the antiglaucoma solutions resulted in markedly lower HCEC toxicity, HCEC damage due to antiglaucoma medication may occur only in rare cases.

\section{Disclosure}

The authors report financial support by Merck and Co, Inc, Whitehouse Station, NJ, USA.

\section{References}

1. Burstein NL. Corneal cytotoxicity of topically applied drugs, vehicles, and preservatives. Surv Ophthalmol. 1980;25:15-30.

2. Aoyama Y, Motoki M, Hashimoto M. Effect of various anti-glaucoma eyedrops on human corneal epithelial cells. Nippon Ganka Gakkai Zasshi. 2004;108:75-83.

3. Noecker RJ, Herrygers LA, Anwaruddin R. Corneal and conjunctival changes caused by commonly used glaucoma medications. Cornea. 2004;23:490-496.

4. Guenoun JM, Baudouin C, Rat P, Pauly A, Warnet JM, BrignoleBaudouin F. In vitro study of inflammatory potential and toxicity profile of latanoprost, travoprost, and bimatoprost in conjunctiva-derived epithelial cells. Invest Ophthalmol Vis Sci. 2005;46:2444-2450.

5. Baudouin C, Labbé A, Liang H, Pauly A, Brignole-Baudouin F. Preservatives in eyedrops: the good, the bad, and the ugly. Prog Retin Eye Res. 2010;29:312-334.

6. Pfister RR, Burstein NL. The effects of ophthalmic drugs, vehicles, and preservatives on corneal epithelium: a scanning electron microscope study. Invest Ophthalmol. 1976;15:246-259.

7. Chou A, Hori S, Takase M. Ocular toxicity of beta-blockers and benzalkonium chloride in pigmented rabbits: electrophysiological and morphological studies. Jpn J Ophthalmol. 1985;29:13-23.

8. de Saint Jean M, Debbasch C, Brignole F, Rat P, Warnet JM, Baudouin C. Toxicity of preserved and unpreserved antiglaucoma topical drugs in an in vitro model of conjunctival cells. Curr Eye Res. 2000;20:85-94.

9. Ishibashi T, Yokoi N, Kinoshita S. Comparison of the short-term effects on the human corneal surface of topical timolol maleate with and without benzalkonium chloride. J Glaucoma. 2003;12:486-490.

10. Pisella PJ, Debbasch C, Hamard P, et al. Conjunctival proinflammatory and proapoptotic effects of latanoprost and preserved and unpreserved timolol: an ex vivo and in vitro study. Invest Ophthalmol Vis Sci. 2004;45:1360-1368.

11. Baudouin C, Riancho L, Warnet JM, Brignole F. In vitro studies of antiglaucomatous prostaglandin analogues: travoprost with and without benzalkonium chloride and preserved latanoprost. Invest Ophthalmol Vis Sci. 2007;48:4123-4128.

12. Nuyts RM, Pels E, Greve EL. The effects of 5-fluorouracil and mitomycin $\mathrm{C}$ on the corneal endothelium. Curr Eye Res. 1992;11:565-570.

13. Ayaki M, Yaguchi S, Iwasawa A, Koide R. Cytotoxicity of eye drops with and without preservatives for human corneal endothelial cells, epithelial cells, and conjunctival epithelial cells. Exp Clin Ophthalmol. 2008;36:553-559.

14. Ayaki M, Noda Y, Yaguchi S, et al. Cytotoxicity of antiglaucoma eye drops for human corneal endothelial cells. Nippon Ganka Gakkai Zasshi. 2009;113:576-582. 
15. Samples JR, Binder PS, Nayak S. The effect of epinephrine and benzalkonium chloride on cultured corneal endothelial and trabecular meshwork cells. Exp Eye Res. 1989;49:1-12.

16. Baratz KH, Nau CB, Winter EJ, et al. Effects of glaucoma medications on corneal endothelium, keratocytes, and subbasal nerves among participants in the ocular hypertension treatment study. Cornea. 2006;25:1046-1052.

17. Ayaki M, Shimada K, Yaguchi S, Koide R, Iwasawa A. Corneal and conjunctival toxicity of disinfectants-assessing safety for use with ophthalmic surgical instruments. Regul Toxicol Pharmacol. 2007;48:292-295.

18. Ayaki M, Soda M, Yaguchi S, Iwasawa A, Koide R. Cytotoxicity of five fluoroquinolone and two nonsteroidal anti-inflammatory benzalkonium chloride-free eye drops in four corneoconjunctival cell lines. Clin Ophthalmol. In press.

19. Ayaki M, Iwasawa A, Yaguchi S, Koide R. Preserved and unpreserved 12 anti-allergic eye drops and ocular surface toxicity: in vitro assessment in four cultured corneal and conjunctival epithelial cell lines. Biocontrol Sci. In press.

20. Ayaki M, Iwasawa A. Cytotoxicity of prostaglandin analogue eye drops (tafluprost, latanoprost, travoprost, and unoproston) preserved with benzalkonium chloride in multiple corneoconjunctival cell lines. Clin Ophthalmol. In press.

21. Liu H, Routley I, Teichmann KD.Toxic endothelial cell destruction from intraocular benzalkonium chloride. J Cataract Refract Surg. 2001;27:1746-1750.

22. Eleftheriadis H, Cheong M, Sandeman S, et al. Corneal toxicity secondary to inadvertent use of benzalkonium chloride preserved viscoelastic material in cataract surgery. Br J Ophthalmol. 2002;86(3):299-305.

23. Hughes EH, Pretorius M, Eleftheriadis H, Liu CS. Long-term recovery of the human corneal endothelium after toxic injury by benzalkonium chloride. Br J Ophthalmol. 2007;91(11):1460-1463.

24. Lemp MA, Zimmerman LE. Toxic endothelial degeneration in ocular surface disease treated with topical medications containing benzalkonium chloride. Am J Ophthalmol. 1988;105:670-673.
25. Lavine JB, Binder PS, Wickham MG. Antimicrobials and the corneal endothelium. Ann Ophthalmol. 1979;11(10):1517-1528.

26. Vareilles P, Silverstone D, Plazonnet B, Le Douarec JC, Sears ML, Stone CA. Comparison of the effects of timolol and other adrenergic agents on intraocular pressure in the rabbit. Invest Ophthalmol Vis Sci. 1977; 16:987-996.

27. Araie M, Takase M, Sakai Y, Ishii Y, Yokoyama Y, Kitagawa M. Betaadrenergic blockers: ocular penetration and binding to the uveal pigment. Jpn J Ophthalmol. 1982;26:248-263.

28. Pisella PJ, Fillacier K, Elena PP, Debbasch C, Baudouin C. Comparison of the effects of preserved and unpreserved formulations of timolol on the ocular surface of albino rabbits. Ophthalmic Res. 2000;32:3-8.

29. Lass JH, Khosrof SA, Laurence JK, Horwitz B, Ghosh K, Adamsons I. A double-masked, randomized, 1-year study comparing the corneal effects of dorzolamide, timolol, and betaxolol. Dorzolamide Corneal Effects Study Group. Arch Ophthalmol. 1998;116:1003-1010.

30. Konowal A, Morrison JC, Brown SV, et al. Irreversible corneal decompensation in patients treated with topical dorzolamide. Am JOphthalmol. 1999; 127:403-406.

31. Giasson CJ, Nguyen TQ, Boisjoly HM, Lesk MR, Amyot M, Charest M. Dorzolamide and corneal recovery from edema in patients with glaucoma or ocular hypertension. Am J Ophthalmol. 2000;129:144-150.

32. Egan CA, Hodge DO, McLaren JW, Bourne WM. Effect of dorzolamide on corneal endothelial function in normal human eyes. Invest Ophthalmol Vis Sci. 1998;39:23-29.

33. Inoue K, Okugawa K, Oshika T, Amano S. Influence of dorzolamide on corneal endothelium. Jpn J Ophthalmol. 2003;47:129-133.

34. Kahook MY, Noecker RJ. Comparison of corneal and conjunctival changes after dosing of travoprost preserved with sofZia, latanoprost with $0.02 \%$ benzalkonium chloride, and preservative-free artificial tears. Cornea. 2008;27:339-343.

35. Guenoun JM, Baudouin C, Rat P, Pauly A, Warnet JM, Brignole-Baudouin F. In vitro comparison of cytoprotective and antioxidative effects of latanoprost, travoprost, and bimatoprost on conjunctiva-derived epithelial cells. Invest Ophthalmol Vis Sci. 2005;46:4594-4599.
Clinical Ophthalmology

\section{Publish your work in this journal}

Clinical Ophthalmology is an international, peer-reviewed journal covering all subspecialties within ophthalmology. Key topics include: Optometry; Visual science; Pharmacology and drug therapy in eye diseases; Basic Sciences; Primary and Secondary eye care; Patient Safety and Quality of Care Improvements. This journal is indexed on Submit your manuscript here: http://www.dovepress.com/clinical-ophthalmology-journal

\section{Dovepress}

PubMed Central and CAS, and is the official journal of The Society of Clinical Ophthalmology (SCO). The manuscript management system is completely online and includes a very quick and fair peer-review system, which is all easy to use. Visit http://www.dovepress.com/ testimonials.php to read real quotes from published authors. 